\title{
Gender Mainstreaming in Collaborative Innovation of Poverty Reduction Policy
}

\author{
Amy Yayuk Sri Rahayu ${ }^{1}$, Krisna Puji Rahmayanti ${ }^{2}$, Ihsanudin ${ }^{3}$ \\ amy_soeroso@yahoo.com ${ }^{1}$, krisnarahmayanti@ui.ac.id 2, ihsanudin.ui@gmail.com ${ }^{3}$ \\ Faculty of Administrative Science, Universitas Indonesia
}

\begin{abstract}
Poverty alleviation is a challenging duty of the developing country. Over the years, Indonesia has succeeded to reduce poverty level through many poverty reduction policies and strategies in national or local level. The fact that women and men are similarly susceptible to poverty caused by different backgrounds and conditions, this research aims to investigate the gender mainstreaming in the policy that involves actors to collaborate in an innovative strategy. This study uses a post-positivist approach based on collaborative innovation theory that involves secondary data. The result will elaborate essentials factors of the poverty reduction policy that is classified using collaborative innovation in Indonesia. This research identifies the gender mainstreaming development in the poverty reduction policy and analyze the impact to the development of the poverty alleviation in Indonesia to achieve a better understanding of the gender mainstreaming. The understanding of the gender mainstreaming in the collaborative innovation of poverty reduction policy in Indonesia will draw a bigger picture of the policy strategy more sensitively by highlighting the conditions in the family level.
\end{abstract}

Keywords: poverty reduction; gender mainstreaming; collaborative innovation

\section{Introduction}

Poverty become main problem both in develop or developing country. Poverty happen because people cannot afford basic needs such as income, education, health, and food house [1]. Poverty in Indonesia also become major challenge of the development. In Indonesia, $10.6 \%$ of the population lives below the national poverty line [2]. This number include $6.5 \%$ in 2016 and 5.7\% in 2017 population with headcount ration at $\$ 1.90$ a day [3]. In 2018, there is a decrease in poverty level to $7.02 \%$ [4], but there is still an urgency to create an inclusive policy to reduce poverty level.

In the poverty reduction policy, the attention to the women also require specific treatment due to the women are more susceptible to the poverty. Women as head of the family are not only have challenge to raise their family as single parents but also have difficulty to secure their financial support [5]. In response to this condition, a gender sensitive policy particularly in poverty reduction policy is critical.

Related to the poverty reduction policy, a collaborative perspective to link the cooperation between stakeholder is required. The collaboration between government and private sector increase the effectiveness of goals achievement compare to solve poverty problem by government themselves [6]. Government can involve non-state actors to make and implement policy [7].

A collaborative perspective become an alternative model to address poverty. Governance network can increase the effectiveness, efficiency, and democracy legitimacy to solve public 
problems through incremental change and also invite innovative collaboration as illustrated in the picture [8]. Collaborative governance become a potential framework to overcome social problem such as poverty.

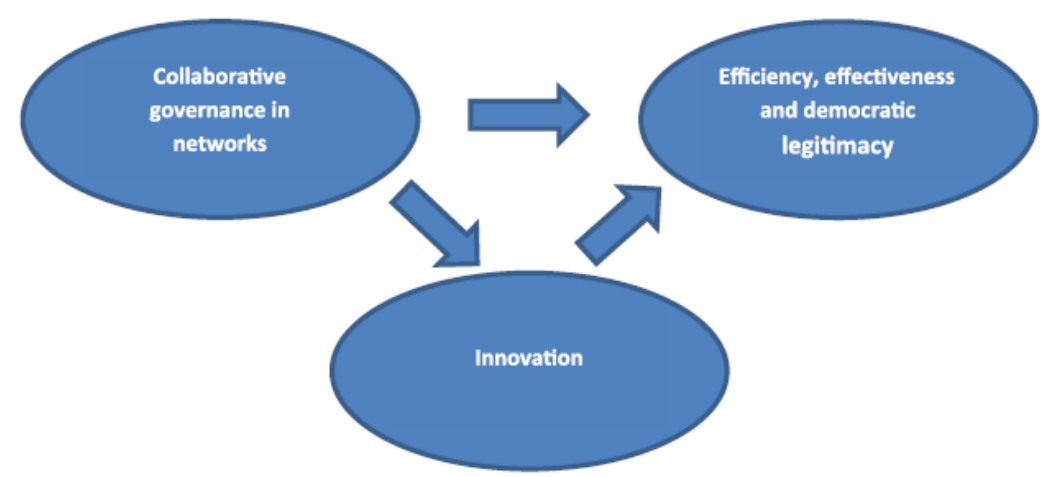

Causal Effect of Governance and Key Performance Source: [8]

A collaboration among actors is kind of innovative policy. Demand of a higher innovation in public sector is increasing as there is higher number of 'wicked problems' such as poverty. Wicked problem is difficult problem to solve which require nonstandard perspective to overcome so its require innovation. The concept of collaborative governance is believed to be wider for understanding the network than merely seeing public sector organizations as managers [9]. Collaborative innovation as a collaborative perspective view innovation and problem solving in public sector which utilize resources and creativity of external and community network to strengthen the progress of vision attainment.

Considering the risk of women in poverty and the chance of innovative collaboration between actors, this study aims to analyze the collaborative innovation among stakeholders particularly in poverty reduction policy which give higher attention to the gender framework. Gender neutral policy is the basic policy which aims to solve social problem. This framework consists of gender neutral, gender specific, and gender redistributive.

\section{Method}

This study use post positivism approach which analyze the problem based on collaborative innovation perspective in the gender sensitive policy framework. Collaborative innovation consist of the analyses of actors, metagovernance, and interactive arena. This study collects secondary data through literature review. This study employed secondary data and literature review to analyses the development of this dimension based on gender sensitive policy framework. 


\section{Result and Discussion}

The discussion of this study will explain poverty reduction policy in Indonesia based on collaborative innovation in the three dimension of gender sensitive policy framework. Collaborative innovation consists of the identification of actors, collaborative area, and meta governance as illustrated in the picture [10]. While gender sensitive policy framework classifies three approach such as gender neutral, gender specific, and gender redistributive.

Picture Analysis Framework of Collaborative Innovation

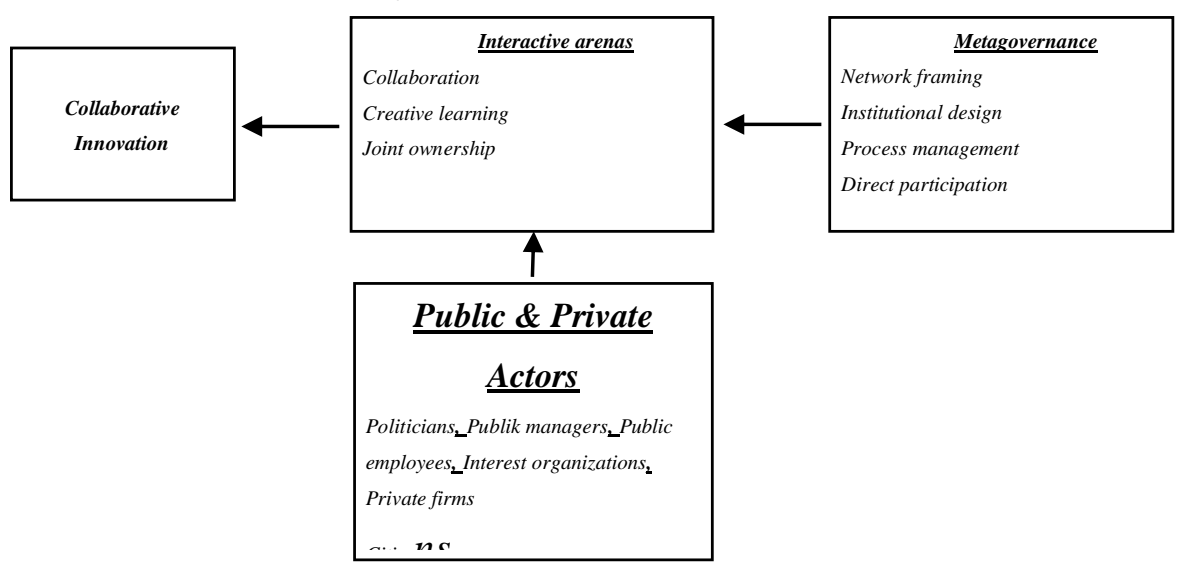

Source:

Firstly, there is an increasing role of public and private actor in the poverty reduction policy and project. The growing trend of poverty reduction policy and project invite several actors such as politician, public manager, public employee, interest organization, private firm, and citizen to engage in the poverty reduction activities. The politician in national and local level have higher involvement to increase further discussion related to the policy which targeted poor people. However, recent development of the poverty reduction framework indicates that there is few politicians who propose a gender sensitive or gender redistributive approach. Current policy in national and local level is still gender-neutral policy. Such as the health protection for the poor, direct provision of grant for the poor, etc.

Even though there is still limited discussion of the gender sensitive policy to reduce poverty in the politic, but private sector and non-government organization have already involved in the poverty reduction program which give special attention to the higher risk of women to poverty. This indicate that in the interactive arena which involve private sector or non-government organization there is the existence of innovative approach to solve social problem. However, the degree of metagovernance is still limited due to limited network framing in every poverty reduction solution. Moreover, the initiative of poverty reduction from private sector or non-government organization are mostly in a specific area with limited budget.

Current trend of the interaction between actors show that the public and private actor can increase the network through the establishment of institutional design. This institutional design can involve not only private sector and non-government organization but also state as 
the most powerful organization in term of resources and network in Indonesia. The institutional design can strengthen the collaboration, creative learning and joint ownership between actors.

Beside there is an urgency to increase the level of collaboration, the poverty reduction need to use gender mainstreaming as the basic perspective to reduce poverty. A gender sensitive or even gender redistributive policy will increase the power of women which eventually will improve the result of poverty alleviation. The more gender sensitive and gender redistribution innovation also become a potential innovative approach among actors both as collaborative project or individual actor's activities related to poverty reduction program.

\section{Conclusion}

The understanding of the gender mainstreaming in the collaborative innovation of poverty reduction policy in Indonesia will draw a bigger picture of the policy strategy more sensitively by highlighting the conditions in the family level. In one hand, current poverty reduction policy indicates that collaborative innovation in poverty reduction have already involved state and non-state actors. Even though meta governance need an improvement. On the other hand, current poverty reduction is mostly a genderneutral policy. Therefore, collaborative innovation or individual organization activities to alleviate poverty need to create a more gender sensitive and gender redistributive policy.

\section{Acknowledgement}

This study is a part of the output of PITTA Grant of 2018 funded by the Directorate of Research and Community Service of Universitas Indonesia

\section{References}

[1] L. M. Asselin, Analysis of Multidimensional Poverty: Theory and Case Studies., Ottawa: Springer, 2009.

[2] Asian Development Bank, "Poverty in Indonesia," Asian Development Bank, 2018. [Online]. Available: https://www.adb.org/countries/indonesia/poverty. [Accessed 17 December 2018].

[3] The World Bank, "Poverty and Equity Data Portal," The World Bank, [Online]. Available: http://povertydata.worldbank.org/poverty/country/IDN. [Accessed 17 December 2018].

[4] Central Bureau of Statistic (Badan Pusat Statistik), "Persentase Penduduk Miskin Menurut Provinsi 2007-2018," Central Bureau of Statistic (Badan Pusat Statistik), 23 July 2018. [Online]. Available: https://www.bps.go.id/dynamictable/2016/08/18/1219/persentase-penduduk-miskinmenurut-provinsi-2007---2018.html. [Accessed 17 December 2018].

[5] A. R. H. L. \&. P. C. Quisumbing, "Are women overrepresented among the poor? An analysis of poverty in 10 developing countrie," Journal of Development Economic, vol. 66, no. 1, pp. 225-269., 2001.

[6] J. D. d. Z. R. J. Donahue, Collaborative Governance: Private Roles for Public Goals in 
Turbulent Times, New Jersey: Princeton University Press, 2011.

[7] C. \&. G. A. Ansell, " Collaborative Governance in Theory and Practice," Journal of Public Administration Research and Theory, vol. 18, no. 4, pp. 543-571, 2008.

[8] E. \&. T. J. Sørensen, "Metagoverning Collaborative Innovation in Governance Network," American Review of Public Administration, vol. 47, no. 7, pp. 826-835, 2017.

[9] K. N. T. \&. B. S. Emerson, "An integrative framework for collaborative governance," Journal of public administration research and theory, vol. 22, no. 1, pp. 1-29, 2012.

[10] E. \&. T. J. Sørensen, Collaborative Innovation in the Public Sector: An Analytical Framework, Roskilde: Roskilde Universitet, 2010. 